\title{
1. Expedition as Time Capsule: Introducing the American-Australian Scientific Expedition to Arnhem Land
}

\author{
Martin Thomas
}

Nineteen Forty-Eight brought little of the quietude that a war-weary world might have wished for. The chill winds of the Cold War were blowing; the great postwar migrations had begun. The time line on the '1948' page of Wikipedia conveys something of the temper of this formative year - or at least a perception of it, collectively created by contributors to that intellectual common. Burma and Ceylon gain independence. Israel becomes a nationstate. Gandhi begins the year with a hunger strike to protest the violence resulting from the Partition of India. In late January, he is assassinated. The Treaty of Brussels, predecessor of the North Atlantic Treaty Organisation (NATO), is signed. The Communist Party seizes control of Czechoslovakia. The Berlin Blockade begins. The World Health Organization is established. Dutch troops and Indonesian nationalists declare a truce. Truman signs the Marshall Plan. An executive order ends racial segregation in the US Armed Forces. The first monkey is launched into space. The paper proposing bigbang nucleo-synthesis as the origin of the universe is published, as is Kinsey's Sexual Behavior in the Human Male. ${ }^{1}$ Not mentioned on the '1948' pagealthough utterly encapsulating the spirit of the moment-is George Orwell on the island of Jura, who has been writing all year. In December, he sends to his London publisher the manuscript that will soon be released as Nineteen Eighty-Four, the title a transposition of four and eight. Nineteen Forty-Eight was nothing if not eventful-and it set the paradigm for many of the most pressing concerns of the present day.

The 17 men and women who officially constituted the American-Australian Scientific Expedition to Arnhem Land were physically quarantined from these events as they went about their research in the far north of Australia. But as this book shows, they, in their way, embodied the zeitgeist, although they did so through participation in a type of activity that is usually associated with the expansion of the European empires, not their falling apart. The Arnhem Land Expedition reminds us that the boundaries between epochs are not always sharply defined; an event constituted on seemingly outmoded principles can be a harbinger of things to come. As much as the expeditionary team was of

1 See $<$ http://en.wikipedia.org/wiki/1948> (viewed 22 October 2010). 
the moment, enacting a display of trans-Pacific harmony that the Australian Government, in particular, was eager to broadcast to the world, the concept of an expedition through the wilds of Arnhem Land was wildly anachronistic, as Anne Clarke and Ursula Frederick explain in their chapter on archaeology. The 1948 Expedition, they write, was an

astounding initiative, not only because of the scale, logistics and multidisciplinary scope of its vision, but also because it was a kind of historical re-enactment - a project that performed the investigative urges of an earlier era in modern times. Like the explorers who mapped the continent in the previous century, the Expedition scholars sought to discover and progress knowledge about a particular region in an effort to better grasp a bigger picture of our world.

One of the great problems for the researchers involved in this enterprise was the rate of change in the world they were trying to picture. By 1964, when the fourth and final volume of the lavish Records of the American-Australian Scientific Expedition to Arnhem Land (1956-64) was published, the whole project had attained something of a sepia hue. In time, scholars would speak of 1948 as 'the last of the big expeditions'. This did not mean that researchers had abandoned locations such as Arnhem Land as destinations for fieldwork; far from it - as many chapters in this volume attest. The problem was with the concept of an expedition, which looked increasingly archaic in a period when decolonisation was forcing revision of the most basic assumptionsespecially those relating to the world's indigenous populations, whose rights and equality were being established in international covenants. These shifting values and mores, which have so coloured our current outlook and perceptions, greatly complicate the task of interpreting the Expedition and its impacts. Clarke and Frederick note that changes in scholarly methods and legal frameworks, added to the completely different ethical considerations that now govern research in Aboriginal communities, have rendered the 'expeditionary approach obsolete'. As we will see, this was anticipated at the time by rival anthropologists who, like later historians of science, tended to ignore the Arnhem Land Expedition or deride it as a populist extravagance. In this book, however, we reject this view, and propose that the fusion of nineteenth- and twentieth-century modes of thinking greatly adds to the interest, complexity and ultimate significance of this event. 


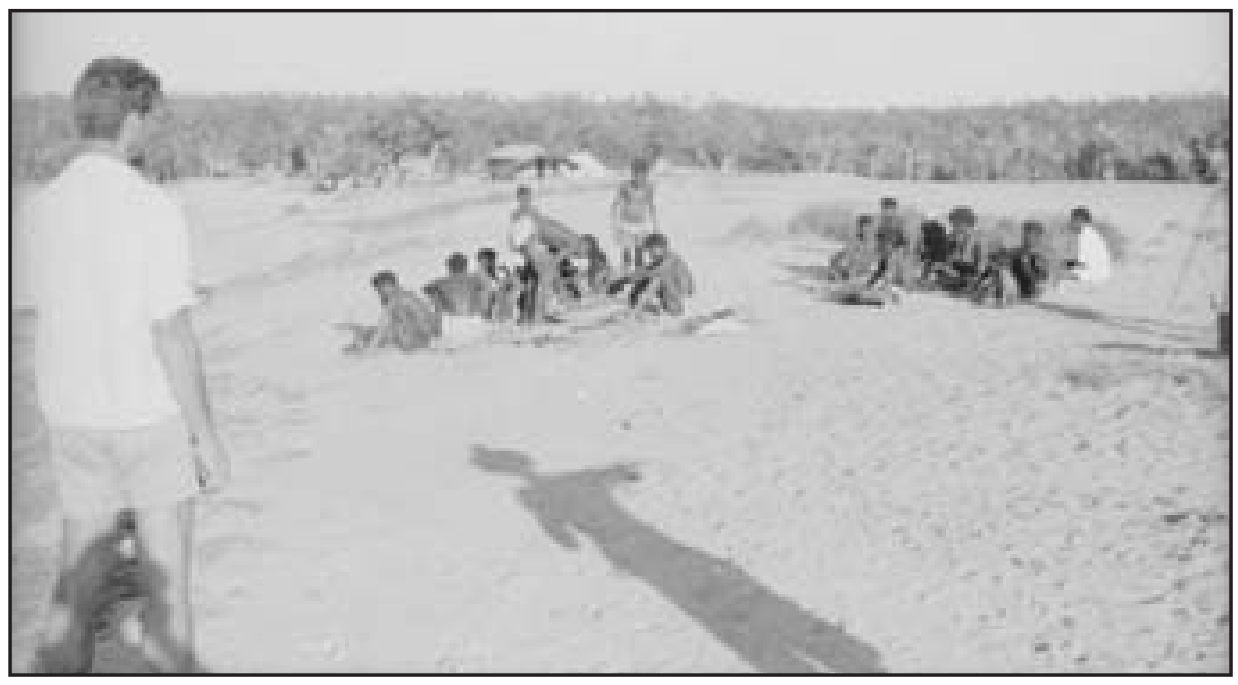

Figure 1.1 Rear view of ichthyologist Robert R. Miller (left) at Yirrkala, with the Expedition camp in the background, 1948

Photograph by Frank M. Setzler. By permission of the National Anthropological Archives, Smithsonian Institution. NAA Photo Lot 36, Box 8.

To get a sense of the world of the Expedition, let us plunge in at the middle. It is July 1948 and the Expedition has reached its fourth month and the second of its three base camps, Yirrkala, on the Gove Peninsula in Arnhem Land's northeast. The clans of this part of Arnhem Land are known collectively as Yolngu, meaning 'people'. The researchers and support team have recently flown in from Groote Eylandt in the Gulf of Carpentaria, where, among the various frustrations that dogged them in those early months, was the delayed arrival of equipment and provisions, owing to the stranding on a reef of their supply barge, the Phoenix. At Yirrkala - and at all the Arnhem Land bases - the visitors are referred to as 'Balanda' by the locals. This term for white people, common throughout the linguistically and culturally diverse terrain of the Arnhem Land reserve, is a loan word - a corruption of 'Hollander' - introduced to Australia by traders who came from the port of Macassar on South Sulawesi to harvest the sea slug known as trepang. ${ }^{2}$ (Their annual visits to northern Australia predate British occupation, although the introduction of the term Balanda indicates that the expansion of the European empires was to some extent known and discussed in Arnhem Land.) The Balanda of the Expedition have pitched large cottage tents at a site called Balma, where the Yirrkala cemetery is now located, and where the grave of Wandjuk Marika (1927-87), a young man who would

2 Macknight, C. C. 1976, The Voyage to Marege': Macassan trepangers in Northern Australia, Melbourne University Press, Carlton, Vic.; and Macknight, C. C. 2008, 'Harvesting the memory: open beaches in Makassar and Arnhem Land', in P. Veth, P. Sutton and M. Neale (eds), Strangers on the Shore: Early coastal contacts with Australia, National Museum of Australia, Canberra. 
serve as one of their main interpreters, can now be found. They are just a stone's throw from the area of the mission known as Beach Camp. With the research and collecting continuing apace, it is a surreal spectacle that the visitors present to the hundred or so people resident at the mission this dry season.

An ornithologist, a mammalogist, an ichthyologist and a botanist are roving the surrounding land and waterways, returning to the camp with bags of specimens. They must preserve them to museum standard, often working until long into the night. Two biomedical researchers have set up a laboratory and are doing their utmost to convince the locals to be pricked and prodded, and to surrender blood, breast milk or faeces to the service of science. Local artists and craftspeople are in overdrive in an effort to satisfy the requirements of three ethnological collectors hungry for paintings, baskets, weapons and other artefacts. The cameras of two photographers snap or whirr as they steadily expose a vast stock of still and moving film. In the middle of the hubbub is the camp kitchen, presided over by a cook who doubles as the honorary entomologist. Like all his colleagues, he is dependent on the input of the local people. A stream of children, whom he refers to as the 'cockroach committee', brings in insects for his collection. Tobacco is the currency for remunerating adults, but the children are paid in sweets.

In his potted accounts of the Expedition's origins, the leader, Charles $\mathrm{P}$. Mountford, always acknowledged the input of three founding fathers. ${ }^{3}$ They were Gilbert Grosvenor, celebrated President of the National Geographic Society (NGS) and editor of its universal magazine; Arthur Calwell, Australia's Minister for Information (who also served as Minister for Immigration and went on to lead the Australian Labor Party in opposition in the 1960s); and Alexander Wetmore, Secretary of the Smithsonian Institution. Grosvenor was the enabler of a research grant that seeded the Expedition. Wetmore, who recognised that Smithsonian participation could rectify his institution's deficiency in Australian collections, offered to send a delegation of scientists. Calwell, who saw the possibility of Australian collaboration with these two iconic US organisations as a diplomatic and propagandist opportunity, arranged to sign up the Australian Government as an official partner (see Jones, Beazley, May and Chapman and Russell, this volume). Mountford was generous in crediting this trio, and seems to have gloried in his association with them. His own diaries, however, reveal a more complex story. In reality, there were many others who played central roles in negotiating what would become the Arnhem Land Expedition. Foremost among them was David Bailey, a journalist and Department of Information press officer stationed on Manhattan, who in early 1945 arranged the itinerary for

3 See, for example, the acknowledgments page in Mountford, C. P. (ed.) 1956, Records of the AmericanAustralian Scientific Expedition to Arnhem Land. Volume 1: Art, myth and symbolism, Melbourne University Press, Carlton, Vic., p. xiii. 
Mountford's film screenings and lectures in the United States and organised meetings with mid-level officials at the Smithsonian, the NGS, the American Museum of Natural History in New York, and other institutions supportive of anthropological research. ${ }^{4}$

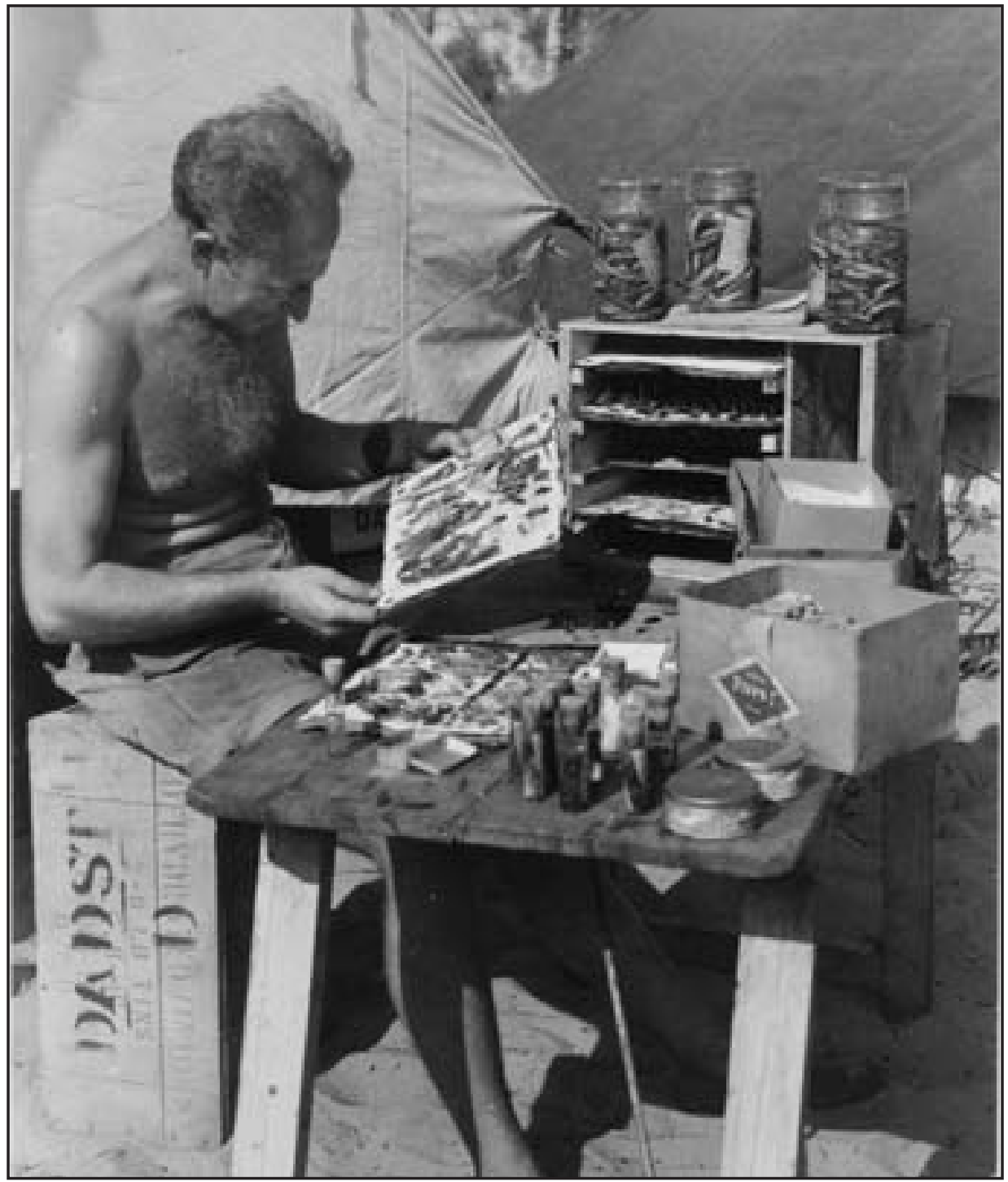

Figure 1.2 Expedition cook and honorary entomologist, John Bray, with his insect collection, 1948

Photograph by Howell Walker. By permission of the State Library of South Australia. PRG 487/1/3.

4 C. P. Mountford, 'A Journey to America 1944-5', vol. 1, PRG 1218/16/1, Mountford-Sheard Collection, State Library of South Australia (hereafter SLSA), Adelaide. 
Of Mountford's major supporters, Wetmore was most alert to the pressures and interpersonal dynamics that complicate the progress of an expedition. His passion for all things to do with birds began in boyhood, and he published his first paper, 'My experience with the Red-headed Woodpecker', at the age of thirteen. Regarded as a '20th-century doyen of American ornithology', he never relinquished his research and collecting - the administrative demands of the Smithsonian secretaryship notwithstanding. ${ }^{5}$ He kept a paternal eye on officers posted to exotic locations, especially the Arnhem Land Expedition ornithologist, Herbert Deignan, with whom he had shared field trips in America, and archaeologist Frank Setzler, the deputy leader. On 9 July, Wetmore wrote to Setzler from his office overlooking The Mall in central Washington, reflecting on the 'affairs of the Australian Expedition', which had been 'much on my mind':

The party now has been long in the field, and has had sufficient of the usual mishaps incident to travel in remote places so that care needs to be used in the personal relationships of the leaders with the men. Let me say that I regard this present trip as one of great importance in furthering friendly relations between scientists and government officers in Australia with the Smithsonian Institution. We must do everything that we can to promote the welfare of the work and the relationships that should exist between the Smithsonian and Australian workers. These, for various reasons, have been more tenuous in the past than I have liked.

Having just celebrated my 62nd birthday I can now look back on nearly 50 years during which I have had active part in many expeditions large and small. I know too well the tensions that develop in the field and the minor incidents that often are magnified by the close contact of individual workers... What I can tell you I wish you would pass on to the three other men in the American party.

Mountford I am sure has had his difficulties, due probably in part to 'politics' among his own countrymen...I have the feeling that he has been put in a very difficult situation due to the delay in transport of supplies and equipment for which he can hardly be blamed personally...I do not know the personnel of the Australian party. Possibly you may have too much information on the subject. There again the personal element enters and we have to do the best we can.

The unforeseen delays will undoubtedly curtail the field work but at that I am not surprised since the program was fairly comprehensive. Regardless of this, whatever we get is so greatly to our advantage here

5 Oehser, P. H. 1980, 'In memoriam: Alexander Wetmore', The Auk, vol. 97, no. 3, p. 608. 
that we should not feel badly. It is always true that a large party has to move more slowly than a small one, which has brought my own personal preference for making most of my own expeditions either alone or with one or two other people. The addition of every new worker means more equipment and more difficulty in transport. As a matter of fact I rather doubt that Mountford through his experience as an anthropologist and photographer realized the extent of the equipment that would be necessary for successful work in other branches when he was developing with me the details of our American party. ${ }^{6}$

Wetmore's letter, so revealing in what it says about the motivations for Smithsonian participation in the Expedition, betrays a suspicion that there was ill feeling towards Mountford, as was certainly the case - and not only among the Americans. Complaints from the Expedition's biochemist and physician, Brian Billington, had reached senior bureaucrats in Canberra. ${ }^{7}$ Furthermore, there are indications that Howard Coate, an employee of the Native Affairs Branch who was delegated to help the party at its first base, Groote Eylandt, criticised Mountford in a report to his superiors. ${ }^{8}$ Even so, Wetmore, when he penned his shrewd advice to Setzler on 9 July, little imagined that the following day Calwell's Director of the Department of Information, accompanied by the Administrator of the Northern Territory and an American diplomat, would fly into the isolated settlement of Yirrkala to declare Mountford unfit for leadership and appoint Setzler in his place. As Philip Jones explains in his account of the incident in Chapter 2, Setzler was eventually persuaded to decline the promotion after conferring with his American colleagues, but the incident remained an enormous humiliation for Mountford and led to further deterioration of an already strained relationship between the two men. ${ }^{9}$ Wetmore, when briefed on these theatrics, confided to Setzler that he was moved to laughter at his earlier 'almost prophetic' letter. Setzler's decision to decline the leadership he thoroughly endorsed; the last thing he wanted was Smithsonian personnel getting bogged down in the trivialities of transport and organisation.

You were absolutely correct in refusing to take over the scientific administration...Mountford's difficulties are the ones usually found in a country where scientific work is not established as fully as it is

\footnotetext{
6 Wetmore to Setzler, 9 July 1948, General Correspondence 1948-9, Folder 1, Frank Maryl Setzler Papers 1927-1960, Box 7, National Anthropological Archives, Suitland, Md.

7 Correspondence in file titled 'Survey Arnhem Land 1947-8', Institute of Anatomy Records, Series No. A2644/1, Item 50/11 Section 1, National Archives of Australia (hereafter NAA), Canberra.

8 Expedition cook, John Bray, made note in his diary that Coate had complained to Native Affairs about Mountford's leadership. The diary is in the private collection of Bray's son, Andrew Bray, of Canberra.

9 For discussion of how the incident was viewed within the US State Department, see Thomas, M. 2010, 'A short history of the 1948 Arnhem Land Expedition', Aboriginal History, vol. 34.
} 
with us. Under such circumstances there is usually more jealousy and contention than cooperation. We had plenty of it in the early days here in the United States. ${ }^{10}$

Wetmore's correspondence shows that to his way of thinking, an expedition of any scale was something of a last resort. So pared back was his own ideal of ornithological fieldwork - a man, a gun, one or two companions - that it was more a bushwalk than an expedition as that term is usually understood. Wetmore was by no means alone in this view. Another sceptic when it came to expeditions was the anthropologist A. P. Elkin - a dominating presence in Aboriginal studies, whose name appears often in this volume. Elkin was the long-serving Professor of Anthropology at the University of Sydney - a position he assumed after his predecessor, A. Radcliffe-Brown, moved to Chicago in 1931. ${ }^{11}$ Elkin had no affection for Mountford, who was of working-class origin and essentially self-trained. For many years, his day job was as a telephone mechanic for the Department of the Postmaster General. Highly gifted as a photographer, he had risen to prominence as an authority on Aboriginal society and culture thanks to the mentorship of museum professionals in Adelaide and through his involvement in amateur societies. His lack of formal credentials was unimpressive to the Chicago-trained Setzler, and it certainly irked Elkin, whom Mountford - with some justification - regarded as his nemesis. Archival records reveal that Elkin waged a sustained campaign against Mountford over many years. He torpedoed a Carnegie grant that Mountford would otherwise have received in 1940 (see Jones, this volume) and in 1947 he queried the award of a Commonwealth Literary Fellowship to Mountford, who proposed writing a book on 'the life and customs of Aborigines of Western Australia'. Elkin wrote to the secretary of the fund that he was 'always a bit suspicious of a title "life and customs"; it savours too much of the travelogue descriptions of the 1880's by untrained observers. These days we look for sociological studies by highly trained men or women.' ${ }^{12}$ When news of the planned Arnhem Land Expedition broke in the Australian press in May 1945, Elkin immediately wrote to the NGS, urging the appointment of 'a trained social anthropologist' and again querying the credentials of Mountford, whom he described as 'a good photographer, especially of still subjects'. Mountford was given a copy of this missive, which he annotated: 'Elkin's letter to National Geographic. Nice man.'13

10 Wetmore to Setzler, 10 August 1948, General Correspondence 1948-9, Folder 1, Frank Maryl Setzler Papers 1927-1960, Box 7, National Anthropological Archives.

11 Wise, T. 1985, The Self Made Anthropologist: A life of A. P. Elkin, Allen \& Unwin, Sydney.

12 Elkin to H. S. Temby, 13 March 1947, Commonwealth Literary Fund Records, Series A463, Item 1948/603, NAA.

13 Elkin to Secretary of NGS, 30 May 1945, Correspondence, 1945-1949, p. 12, PRG 1218/17/4, MountfordSheard Collection, SLSA. 
The struggles between Mountford and Elkin expose disciplinary fault lines that were a defining characteristic of anthropology in this formative period. This is just one of the ways in which the 1948 Expedition provides insight into the world of which it was part. Elkin was undoubtedly thinking of Mountford when he wrote to Setzler in 1950, by which time the American was home in Washington, DC, accessioning the material he had collected in Australia and writing up his reports. Among other business, Elkin mentioned his own trip into southern Arnhem Land the previous year, explaining that he took an expedition which normally I severely refrain from doing, but in addition to studying social organisation and ritual I got recordings of native chants, secret and public' ${ }^{14}$

Elkin's preferred model of fieldwork, which became ever more standard among social anthropologists after World War II, required the researcher to live in a community for an extended period and hopefully become conversant in the language. For many who did this, the experience of social immersion was the prelude to a lifelong commitment to those communities. Jones in this volume likens the long-term approach to 'careful angling across several seasons', in contrast with Mountford's expeditionary method, which 'was more like an afternoon's intensive trawling'. Yet as Elkin himself realised, the driftnet could be useful on occasion, not only because it allowed for rapid and diverse results, but because the collaboration of a range of experts would - in theory at least - result in productive synergies. In addition, the expeditionary approach, which often involved professional filmmakers and photographers, allowed an academic such as Elkin to compete for the substantial audienceinterested in Aboriginal issues - that maligned 'amateurs' such as Mountford were doing much to cultivate. Collaborators in Elkin's 1949 venture included 'my Linguist, Dr. Capell', the archaeologist N. W. G. Macintosh, and Jesse Buffum, an American photographer who 'gave me some beautiful movies'. Bill Harney, the bushman, writer and retired Native Affairs patrol officer who had served as guide for Mountford from July to November 1948, helped liaise with Aboriginal groups and managed the camp. ${ }^{15}$ The recording of 'native chants' was overseen by another participant, poet and broadcaster John Thompson, the adoptive father of actor Jack Thompson and a distinguished radio producer for the Australian Broadcasting Commission (ABC; now Corporation). This was a mutually beneficial arrangement, with the $\mathrm{ABC}$ acquiring unique ethnographic material that it put to immediate use in a documentary feature and then retained in its sound effects library for future productions. In return, the ABC supplied a producer, technician and recording equipment, and allowed Elkin to publish songs on vinyl as a resource for other researchers (see Barwick and Marett, this volume).

14 Elkin to Setzler, 1 June 1950, General Correspondence 1950, Frank Maryl Setzler Papers 1927-1960, Box 8, National Anthropological Archives.

15 Ibid. 
Expeditions were an old idea, but new media permitted a partial reconfiguration of what they were about. Portable sound recording, smaller $16 \mathrm{~mm}$ cameras, colour photography and cheaper methods of reproducing it resulted in interesting alliances between scientific and media organisations. ${ }^{16}$ National Geographic was the pioneer in this regard, for it had had a foot in both media and science since 1899 when the young Gilbert Grosvenor was recruited as editor and rapidly transformed it from a learned journal to a popular pictorial magazine. Mark Collins Jenkins in his chapter on Expedition photographer, Howell Walker, explains how the popular geography promoted by National Geographic was made possible by channelling the proceeds from magazine subscriptions into NGS expeditions and other ventures - ostensibly intended at scientific advancement although very much concerned with the generation of future content. Examination of Elkin's papers suggests that the idea of harnessing the $\mathrm{ABC}^{\prime}$ 's technical resources was a direct result of him listening to the new genre of radio documentary, and discerning its ethnographic possibilities. ${ }^{17}$ That is to say, Elkin did not directly emulate his despised rival. Nevertheless, Elkin's collaboration with Thompson in 1949 was very similar to that between Mountford and the ABC's Colin Simpson the previous year. Simpson met up with the Arnhem Land Expedition at its third base, Oenpelli (now known as Gunbalanya). Working with technician Ray Giles, he initiated a program of audio recording that included documentation of song, ceremony, environmental ambience and interviews with the Expedition members. To advance scholarship on Aboriginal culture, while communicating with a national audience, was seen as highly beneficial to the researchers and, as Tony MacGregor observes in his chapter on Simpson, was concordant 'with the state broadcaster's sense of high national purpose'.

MacGregor provides in-depth analysis of Simpson's audio documentary Expedition to Arnhem Land, which was first broadcast in late 1948 and quickly repeated the following year in a new weekly timeslot called Australian Walkabout. In a departure from the studio-made product that had dominated the airwaves since the inception of radio, advertisements for the program promised listeners the novelty of hearing 'Actual Voices of Australian Personalities' recorded on location. Documentary was a rapidly emerging genre at this time; Expedition cinema-photographer, Peter BassettSmith, noted in his oral history that before the war he had never heard the word 'documentary', despite his passion, dating from boyhood, for filming

\footnotetext{
16 For an account of the effect of technological change on documentary making, see Musser, C. 1966, 'Engaging with reality', in G. Nowell-Smith (ed.), The Oxford History of World Cinema, Oxford University Press, UK.

17 Thomas, M. 2007, 'The rush to record: transmitting the sound of Aboriginal culture', Journal of Australian Studies, no. 90, p. 109.
} 
actuality. ${ }^{18}$ The rise of documentary, which was greatly enabled by the spread of television, transformed the representation of adventure to exotic places, just as it influenced the organisation and financing of this type of travel. The 1953 ascent of Mount Everest by Edmund Hillary and Tenzing Norgay - who used bottled oxygen at the higher altitudes - is emblematic of what happened to the concept of the expedition in the postwar era. 'Blank' spaces on maps were now so scarce that the rhetoric of geographic exploration and discovery became increasingly implausible. Enabled by such innovations as cylinder oxygen, synthetic ropes and fabrics, and improved survival equipment, expeditions morphed into something approximating an extreme sport. It is notable that the word 'expedition' was little used when the drive for exploration took its most extreme turn by abandoning the Earth altogether. In its quest to reach the heavens, the space race required a religious terminology. Astronauts go on missions, not expeditions.

\section{*}

Even as the space race rumbled into action, the documentation of terrestrial travel - much of it carefully staged for the camera - remained important to the way nations made images of themselves, whether they be for distribution abroad or domestic consumption. Cinema spawned the Arnhem Land Expedition, for it was Mountford's films of Central Australia, shot in the early 1940s, that aroused the interest of American backers when he toured the United States in 1945. Cinema kept the Expedition story alive in the 1950s and after, in part through the NGS silent film production, shot by Howell Walker, to which Setzler lectured before audiences of thousands (see Harris, this volume), and through four Australian productions, based on Bassett-Smith's footage and released by the Commonwealth Film Unit. The titles included Arnhem Land, a celebratory chronicle of the Expedition and its achievements, and the nature film Birds and Billabongs (which suggested the title for the symposium that inspired this volume).

18 Peter Bassett-Smith in interview with Sally K. May and Martin Thomas, 12 February 2006, Kangaroo Ground, Vic., ORAL TRC 5655, National Library of Australia Oral History Collection (hereafter NLAOHC), Canberra. 


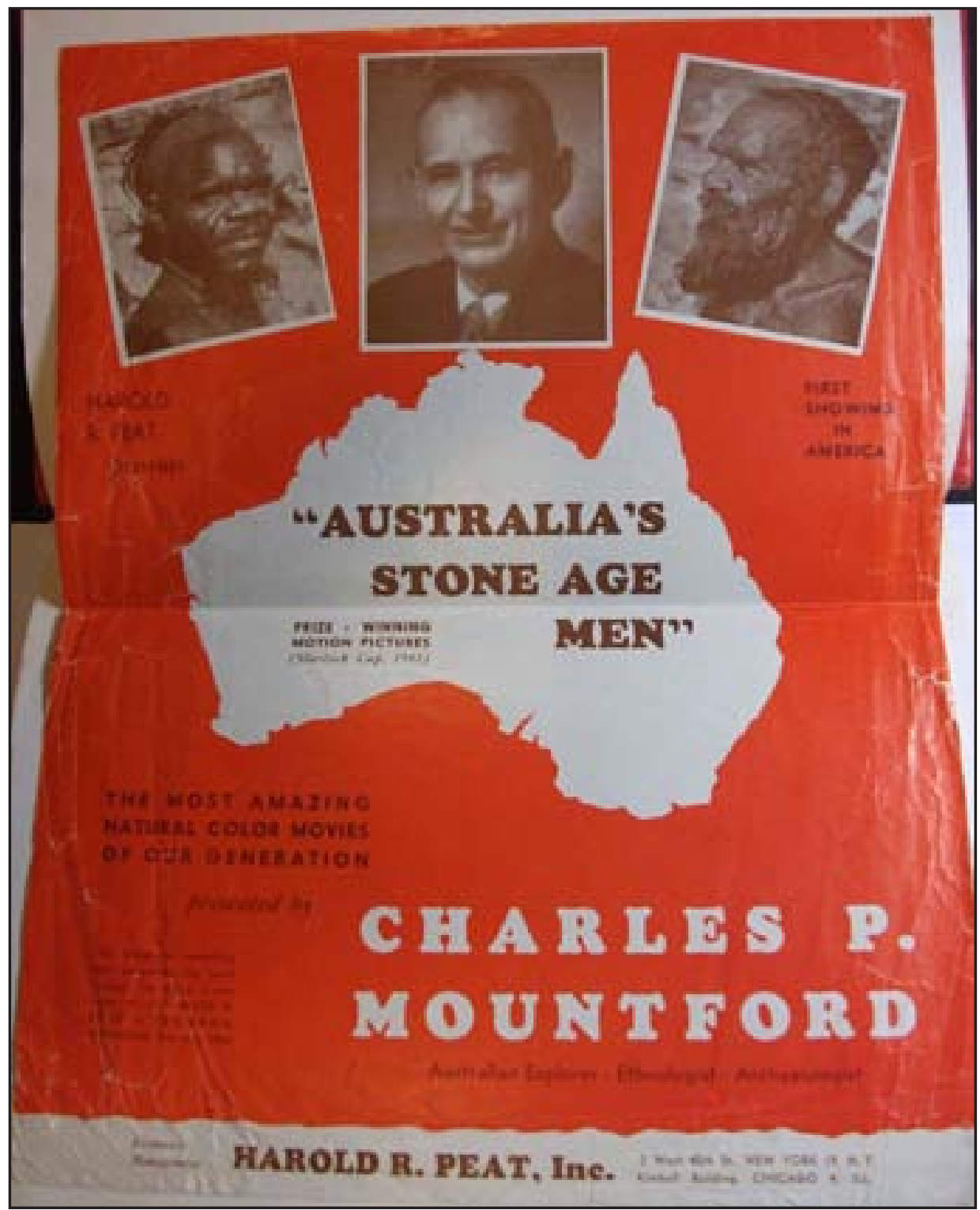

Figure 1.3 Advertisement for Mountford's 1945 film and lecture tour of the United States, inserted in his diary

By permission of the State Library of South Australia. PRG 1218/16/2.

The short production time of radio feature making allowed the Australian national broadcaster to carry the first documentary on the Expedition. Simpson's program first went to air on 30 November 1948, less than four weeks after the party's departure from its final base, when much of the film stock had yet to be processed. The production opens not with 'actual voices', but with a heady dose 
of orchestral fanfare. It is film music, 1940s-style. Trumpets blare; strings and percussion stamp out a rhythm that conjures a vision of pith-helmeted white men leading native carriers through fake jungle. A most un-Australian voice announces: 'Expedition to Arnhem Land-an ABC feature program.' Perhaps it is all a little tongue-in-cheek, for at this moment a cross-fade occurs and the studio-confected journey into the heart of darkness is suddenly replaced with music from Western Arnhem Land: a beautiful ensemble performance involving singers accompanied by clap sticks and didjeridu. ${ }^{19}$ That staged transition from 'artifice' to 'reality' is highly prescient. In compressed form, it seems to register the shift from prewar to postwar mind-set, anticipating the broader concern for Aboriginal heritage that the Expedition helped foster-partly through Simpson's own travel writing, particularly his bestselling book stimulated by his 1948 experience, Adam in Ochre (1951), which argued for the legitimacy of Aboriginal culture and made withering critique of white Australia's treatment of the people it dispossessed. The didjeridu we now regard as a quintessentially Australian sound-as iconic to the nation as the gum tree or the kangaroo. So it is salutary to realise that this became possible only because of specific collaborations involving Aboriginal musicians and non-Aboriginal recordists. ${ }^{20}$ For the majority of listeners to Simpson's program, it was their first hearing of the instrument. By MacGregor's reckoning, it was only the second time that a didjeridu recording had been broadcast (see MacGregor, Note 39).

Expedition to Arnhem Land contains interviews with most of the researchers, commencing with Mountford, who explained the purpose of the mission:

SIMPSON: And the nature of this expedition, Mr Mountford, it's not an exploring expedition is it, going into darkest Arnhem Land to contact savages who don't exist any more? It is a scientific expedition, is that right?

MOUNTFORD: That is so. This is not an exploring party, its objects are purely scientific and that is to increase our knowledge of the natural history and the Aborigines of Arnhem Land.

Mountford's deflection of Simpson's scepticism is revealing. In Western cartographic terms, Arnhem Land was for the most part mapped and 'known'. Topographical charts and large aerial photographs were made available to the researchers long before they began their journey (see McCarthy and Daly, this volume). Relieved of the challenges of terrestrial exploration, Mountford's

19 Simpson, C. 1948, Expedition to Arnhem Land, ABC documentary, first broadcast 30 November 1948, Australian Broadcasting Commission, Sydney.

20 For discussion of the origins and history of the didjeridu, see Moyle, A. M. 1981, 'The Australian didjeridu: a late musical tradition', World Archaeology, vol. 12, no. 3; and Neuenfeldt, K. 1997, The Didjeridu: From Arnhem Land to the Internet, John Libbey and Perfect Beat Publications, Sydney. 
interest in penetrating the unknown was readily channelled to the frontier of knowledge. The 'natural history and the Aborigines' - a most telling conflation - were presented as terra incognita.

The decision to combine anthropological and environmental study was a significant departure from the academic anthropology of mid-twentieth century Australia, and it is key to the uniqueness of the Arnhem Land Expedition. As Jon Altman explains in his chapter on the work of nutritionist Margaret McArthur, the Expedition's study of food gathering in relation to environmental and seasonal influences would mark its most pronounced contribution to social anthropology. An indication of why the Expedition's ethnological inquiries were steered in the direction of environmental study is revealed in Mountford's US diary for 6 February 1945, where he describes a lunch at the Cosmos Club in Washington, DC, attended by personnel from the Smithsonian's Bureau of American Ethnology. Also present was the Harvard anthropologist and racial theorist Carleton S. Coon, who in 1954 would go to Australia and participate for a time in Mountford's NGS-sponsored research on Melville Island. Coon arrived early at the club and spoke to Mountford about problems he discerned in Australian anthropology. He criticised the work of both Elkin and W. Lloyd Warner, a prominent Chicago anthropologist who had made his name with work in Arnhem Land in the late 1920s. According to Mountford's record of the conversation, Coon believed that

how a people should be studied is to examine them in relation to their environment, the foods they eat, their method of gathering it, obtaining the necessities of life, the design of their laws to prevent disturbances and when they do occur, how they are righted.

He condemned what he called the Elkin-Warner complex, which based everything on the social organisation. That, Coon claimed was secondary. The relationship of the man to his surroundings, physical and spiritual was all important.

That coincides with my idea, although I could not put it as well as he did. We are inclined not to see the wood for the trees. We've always worked from the outside in, not the inside out, an outlook which I think my study of the legends has given me. ${ }^{21}$

The conversation at the Cosmos Club continued with the arrival of other lunch guests, among them William N. Fenton, the distinguished Iroquois specialist'a young chap who has read a deal of Australian ethnology, but then considers he knows little about it' - who was then working for the Bureau of American Ethnology. While the prospect of NGS funding for an Australian expedition had

21 C. P. Mountford, 1944-45, A Journey to America 1944-5, vol. 2, pp. 88-91, PRG 1218/16/2, SLSA. 
already been raised, and was discussed during the luncheon, the possibility of direct Smithsonian funding, probably for a project in Central Australia, was also on the table. This idea went no further when planning for the Arnhem Land Expedition took off. As always, Mountford was attuned to the academic machinations within his own country. 'Politically, it's all very complex because the moment they [the Smithsonian Institution] ask, the Commonwealth Government will go to Elkin, and that will scotch my chance.' ${ }^{22}$ Mountford's account of the luncheon is intriguing for what it reveals about the fault lines extant in American anthropology, and how they intersected with those in Australia. Coon's criticism of Elkin was music to the ears of Mountford, and the suggestion that environmental study would mark a progressive departure from Elkin's brand of social anthropology was subtly incorporated into his application for NGS funding. The topographical diversity of Arnhem Land was emphasised and Warner was mentioned only as having 'dealt largely with social organization' and 'ceremonial observances' ${ }^{23}$

The Bureau of American Ethnology - a division of the Smithsonian Institution that lasted (under various names) from 1879 until 1965-was famous for its anthropological studies of Native American culture, which were published in annual reports and regular bulletins. Despite an archaeological focus in its early decades, it had come to put 'greater emphasis on linguistics and ethnography' by the early twentieth century. ${ }^{24}$ The Smithsonian also had a quite separate Department of Anthropology within the US National Museum (now the National Museum of Natural History), and, almost inevitably, there was rivalry between the two. Mountford's personal contact with Fenton and Henry B. Collins, another bureau employee, made it likely that one of them would have gone to Arnhem Land once the NGS funding was approved and the Smithsonian committed itself to the Expedition. Fenton related in his 2007 memoir that he 'had been slated' to go to Arnhem Land, but that Wetmore decided to 'replace me with Frank Setzler [of the US National Museum], whom Wetmore had elevated to head curator, thereby creating an uproar' ${ }^{25}$ The appointment of Setzler to the Expedition was highly significant. Fenton was a cultural anthropologist with a distinguished record of collaborative involvement in Native American communities. That he might have brought this experience to Australia is a tantalising thought. Setzler was an altogether different figure. Although trained in anthropology, he was by disposition an archaeologist. ${ }^{26}$ Many of his publications concerned the

\footnotetext{
22 Ibid., p. 91.

23 Application to Chairman of the Research Committee, National Geographic Society, 5 March 1945, Correspondence 1945-49, vol. 1 1945-47, PRG 1218/17/4, American-Australian Scientific Expedition to Arnhem Land 1948 Records, SLSA, p. 4.

24 Woodbury, B. and Woodbury, N. F. S. 1999, 'The rise and fall of the Bureau of American Ethnology', Journal of the Southwest, vol. 41, no. 3, p. 286.

25 Fenton, W. N. 2007, Iroquois Journey: An anthropologist remembers, University of Nebraska Press, Lincoln, p. 135.

26 Davis, M. 2007, Writing Heritage: The depiction of Indigenous heritage in European-Australian writings, Australian Scholarly Publishing, Kew, Vic. See also Clarke and Frederick, this volume.
} 
Hopewell mounds of the north-eastern and mid-western United States. With no real interest in ethnography, his reputation as a fieldworker was founded on his many excavations of Native American sites. These included a number of burial sites - experience that he would put to use in Arnhem Land. ${ }^{27}$

Setzler's leanings towards archaeology and the collecting of material culture dovetailed with Mountford's own preoccupation with bark paintings, to the extent that competition for collections drove a wedge between them. While Mountford argued in his grant application for a synthesis of ethnological and ecological study, he never abandoned his basic commitment to the collection of objects, inculcated during his long association with the South Australian Museum, as is apparent in his essay 'The Story of the Expedition', which opens the first volume of the records:

The results of the expedition could hardly have been richer, both from the standpoint of human companionship and scientific results... The gross results of the collections, too, were impressive: 13,500 plant specimens, 30,000 fish, 850 birds, 460 animals, several thousand aboriginal implements and weapons, together with photographs and drawings of a large number of cave paintings...There was also a collection of several hundred aboriginal bark paintings and two hundred string figures. In addition to the physical collections of natural history and ethnological specimens, each scientist had written extensive field notes as a basis for his scientific papers. There were also many hundreds of monochrome and coloured photographs as well as several miles of colour film on aboriginal life and natural history. ${ }^{28}$

Mountford championed their success not in terms of new theories or ideas, but in numbers of specimens. As a contribution to science, the Expedition was measurable by the ton or the yard. As Robyn McKenzie observes in her chapter on string-figure collecting, the preoccupation with metrics was 'a currency' shared by nearly all team members: it was 'the measure of their work both for themselves and others'. This stockpiling of objects to be warehoused in museums for future study connects the 1948 Expedition with the well-established assumption that the collecting and categorising of objects inevitably results in the advancement of knowledge. This confidence in the equation that taxonomic achievement equals scientific advancement makes the 1948 project a latter-day example of a tradition that became entrenched with key explorations of the Enlightenment period, of which Cook's voyages are paradigmatic. In mounting and laboriously promoting his high-profile venture, Mountford was consciously

27 Information drawn from Frank M. Setzler Biographical File, RU 7098, Smithsonian Institution Archives, Washington, DC

28 Mountford, Records of the American-Australian Scientific Expedition to Arnhem Land, vol. 1, p. xxx. 
connecting himself with this heroic history. The hubris that is almost endemic to the expeditionary model is evident in Mountford's more hyperbolic rhetoric, which memories of those who conspired against him would sometimes unleash. In a 1966 interview, he recalled having 'a lot of trouble getting the expedition through, because here was I with the status of little more than a telephone mechanic, taking out the biggest scientific expedition in history, and what the academic world tried to do to me was nobody's business!' ${ }^{29}$

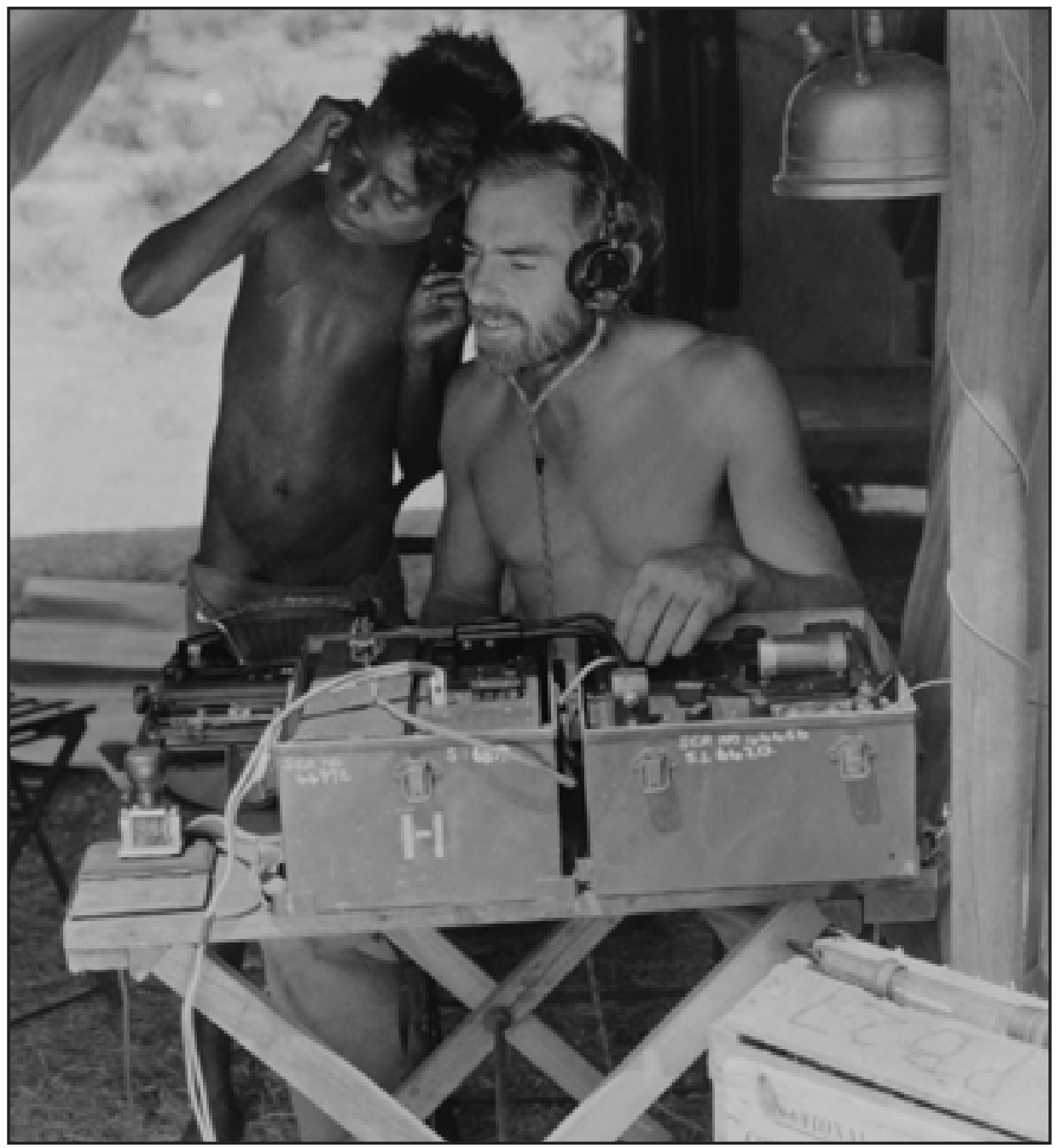

Figure 1.4 Cinema-photographer Peter Bassett-Smith demonstrating the Expedition radio to an unidentified boy, 1948

Photograph by Howell Walker. By permission of National Geographic Stock.

29 Mountford in interview with Hazel de Berg, 28 October 1966, Hazel de Berg Collection, Oral DeB 189, NLAOHC. 
As I note in my chapter on Gerald Blitner, who was a guide and translator to the Expedition on Groote Eylandt, Mountford and his team produced a plethora of photographs and other images 'where Aboriginal performers have their voices recorded or watch with fascination as the visiting scientists go about their work, busy at the technological forefront'. The researchers themselves are on display in these images; science must not only be done, but seen to be done by as large an audience as possible. All of this is a reminder (if any is needed) that the expedition is a uniquely Western mode of moving through space and acquiring knowledge. Indeed, given its centrality to empire building in the exploratory phases, the notion of the expedition is central to the very construction of the idea of 'the West' and the claimed advancement of Western over other societies. An expedition is by definition much more than a journey. To qualify as such, an expeditionary party must leave more than footprints. Typically, it will dislocate living or non-living objects from the environment it traverses, transforming them into specimens; invariably, it will produce maps, pictures or written documents. In a highly formalised way, the expedition fuses travel and textual production.

Given that the traversing of 'unknown' territory nearly always involves contact with peoples of different cultures, there is a highly performative aspect to an expedition. This makes it the subject of observation, as much as it is a vehicle from which to observe. That is part of the reason why hierarchical display is pivotal to the expedition as an expression of power. At the peak is a leader whose name is often immortalised through attachment to the expedition. Below him (my gender specificity is intentional) is a deputy and then the middle ranks, and at the bottom the typically anonymous - and very often indigenousguides and carriers, on whom it all depends. Consciously or unconsciously, the expedition cultivates a microcosm of the society it represents, projecting it into foreign territory. An expedition is a type of activity, but it is also a genre; it is a distinctive and self-perpetuating mode of moving, acting, organising and writing. It is not surprising that the ethnographers in the 1948 team took with them copies of Warner's A Black Civilization - the most significant contribution to Arnhem Land anthropology then published-and other texts about the region they were visiting (see Hamby and Thomas, this volume). Processing the current journey through the lenses of earlier travellers-cum-authors is crucial to the ongoing life of the genre.

Of course, the expedition-as-microcosm is always a selective depiction of the society that produced it. That is part of its fascination. The competing demands of sponsors and host institutions, and conflicting desires and expectations within the expeditionary party, create estrangements and entanglements that expedition members must deal with in the course of the journey - and often, as is the case here, for years after it is over. That is why an account of the Arnhem 
Land Expedition involves so much more than those months in the field. We must seriously engage with the forces that shaped it. In so doing, we obtain a rich perspective on the historical context of this extraordinary event. From various points of view, these influences are scrutinised in the chapters ahead. Kim Beazley, whose father served in Chifley's government and who himself is a veteran of Labor politics, connects the Arnhem Land Expedition with the vision of postwar nation building held by Ben Chifley's government, for whom scientific advancement and the fostering of a home-grown research culture were crucial. Related developments include the establishment of the research-focused Australian National University in 1947. Beazley describes how the pressures of the Cold War, the looming possibility of an alliance with the United States, the rethinking of the relationship with Britain, and the tussles between the proAmerican Calwell and the internationally minded Minister for External Affairs, H. V. Evatt, left their imprint on the Arnhem Land Expedition.

Born of strategic considerations, the Expedition made its own transit through a range of political contexts. If its genesis was in the lofty realm of international relations, its destination was the parochial world of the Northern Territory, where Arnhem Land is located. At the time of the Expedition, the Territory had a very new Legislative Council, partly appointed and partly elected. It met for the first time in February 1948. In the small town of Darwin, where the researchers congregated in March and waited for weather sufficiently calm to allow them to fly to Groote Eylandt, the Administrator, A. R. Driver, wielded considerable authority. The administration's file on the Expedition has recently come to light, and it reveals a bureaucracy indignant at having to deal with this oversized inconvenience, thrust upon them by distant masters. ${ }^{30}$ Out in the field, Mountford and his company confronted another sphere of white authority: the people who ran the official Aboriginal settlements. Mountford had championed Arnhem Land as a suitable locale for research because it was a 'Stone-Age' world that the twentieth century had bypassed. ${ }^{31}$ Yet two of their three bases were Christian missions (Yirrkala and Oenpelli), while the other, Umbakumba on Groote Eylandt, was a less orthodox set-up: a 'native settlement' privately established and operated by the expatriate Englishman Frederick Gray (see Thomas, this volume). Gray was an honorary Aboriginal Protector and his settlement had the reluctant blessing of Native Affairs, the Commonwealth bureaucracy responsible for Aboriginal welfare in the Northern Territory. At each of these locations, Mountford was required to deal with the quixotic array of individuals in positions of authority. It was a latter-day frontier situation, where Balanda - or in the case of Yirrkala, Fijian-missionaries dictated the

30 File titled 'Scientific Expedition to Arnhem Land \& NT-C. P. Mountford', Series F1, Item 1945/151, NAA, Darwin.

31 Thomas, M. 2010, 'A short history of the 1948 Arnhem Land Expedition', Aboriginal History, vol. 34, p. 148. 
daily routine of residents, wielding in many instances an extraordinary level of power. The researchers had to pick their way around these obstacles and at the same time negotiate the most complex transaction of them all: the cross-cultural one. To have any chance of fulfilling its stated objectives, the Expedition needed to establish collaborative partnerships with the traditional owners of the country they were visiting.

So we find in the Expedition an event thickly inscribed with the political complexities of its epoch. It occurred at a seminal moment post World War II and was directly influenced by the shifting geopolitics of the period. In its organisational structure, it carried the residue of earlier imperial ambitions, yet it embodied the contemporary moment by embracing new media and by anticipating shifts in the natural sciences, particularly the more holistic outlook of ecological thinking. As Lynne McCarthy emphasises in her chapter on botany, exploring the relationship between people and their environment is axiomatic to an ecological approach. The Expedition was at odds with mainstream values in treating the Aboriginal cultures of northern Australia as valid knowledge systems, worthy of greater understanding.

For these reasons, the Arnhem Land Expedition can be thought of as a time capsule. The metaphor is particularly appropriate given its basic concern with the amassing of objects. At the kernel of our time capsule is that vast array of collections - ranging from bottled fish to works of art-headily described by Mountford in his summation of their accomplishment. Admittedly, the contents of the capsule are anything but concentrated. The location of the collections reflects the plethora of interests that had a stake in the venture and therefore a claim to its material rewards - an often disputed process, as Sally K. May has shown. ${ }^{32}$ Substantial holdings of natural-history specimens and ethnographic objects are held in the National Museum of Natural History at the Smithsonian Institution. Insects, bark paintings, string figures and other examples of Aboriginal material culture are held in the Australian Museum, Sydney. The South Australian Museum and the National Museum of Australia in Canberra have ethnographic holdings. The art galleries of all six Australian states possess ochre paintings on bark and paper, while botanical collections are held by some of the world's leading herbaria. When we add to these varied riches the films, photographs and sound recordings, and the vast written record kept by Expedition members and others, many of whom were fastidious note takers, letter writers and diarists, the full significance of the Expedition-as-timecapsule becomes apparent - as does the daunting task of trying to decode it.

32 May, S. K. 2010, Collecting Cultures: Myth, Politics, and Collaboration in the 1948 Arnhem Land Expedition, Altamira Press, Lanham, Md. 
The size of the collections - and their dispersal across two continents - explains why the Arnhem Land Expedition has tended to defy interpretation as a whole. Sally May's book Collecting Cultures (2010), launched during the Barks, Birds \& Billabongs symposium, marks the first attempt to synthesise data from the US and Australian collections. Overall, the amount of scholarship on the Expedition has been incommensurate with the scale and significance of the event. While this book - to which more than 20 writers have contributed - is a substantial unpacking of the capsule, all of us would acknowledge that the work of interpretation has only begun. Just as a time capsule betrays the mindset of those who packed it, the readings of the Expedition that make up the following pages reveal the predispositions of the unpackers. Offered here is a dialogue, with continuities between past and present forming one strand of the discussion. Disjunctions are another. The latter become particularly prominent in the later chapters where the effects of the Expedition upon Arnhem Land cultures, past and present, are considered. When Mountford argued for the benefits of the Expedition, its impact (positive or negative) upon the people who would provide the intellectual capital was not considered for a moment. Many friendships developed between researchers and members of host communities, but their hopes, feelings and aspirations were, in the broader scheme of things, largely ignored. Murray Garde and Ian McIntosh take up this issue in their discussions of secret-sacred ceremony and objects, which the Expedition made public in films, exhibitions and still photographs. At best, the public use of this footage was not negotiated with traditional owners. Gerald Blitner claimed more controversially that senior men sanctioned filming of the secret ceremony on Groote because Mountford promised that it would be used for research purposes only (see Thomas, this volume). Notably, Mountford never challenged the most controversial activity that occurred under his leadership: the removal by Frank Setzler of human remains from mortuary caves and burial sites. The collection of skeletal material was not advertised in Mountford's inventory of trophies - a revealing omission. Nearly all the bones were exported to the United States, where they were accessioned into the collection of the Smithsonian's US National Museum. Bone collecting was never mooted in the build-up to the Expedition, and, in contrast with the collecting of native fauna, for which permits were required, no arm of government approved the harvesting of graves. These remnants of human beings are - or were - a crucial element of the Expedition-as-time-capsule. The issue has caused sadness, anger and bewilderment in Arnhem Land, and deep frustration among certain personnel at the Smithsonian, owing to resistance to a decision to repatriate the remains after extensive lobbying by Australian officials. They pointed out that early in the planning of the Expedition, the Smithsonian Institution and the Department of Information came to an agreement that two-thirds of all specimens collected should remain in Australia. The Smithsonian eventually accepted this, and, in 2008, the institution returned this proportion of its holdings of Arnhem 
Land human remains to a delegation of traditional owners. Requests that the remaining third should also be returned were resisted by the Department of Anthropology. Lobbying by the Australian Government continued, and, in July 2010, in the wake of the Barks, Birds \& Billabongs symposium and an embarrassing media report on the Smithsonian's intransigence over this issue, the rest of the human remains were released to three traditional owners from Arnhem Land. The handover was formalised at a moving ceremony held in the Cultural Resources Center of the Smithsonian Institution's National Museum of the American Indian. ${ }^{33}$

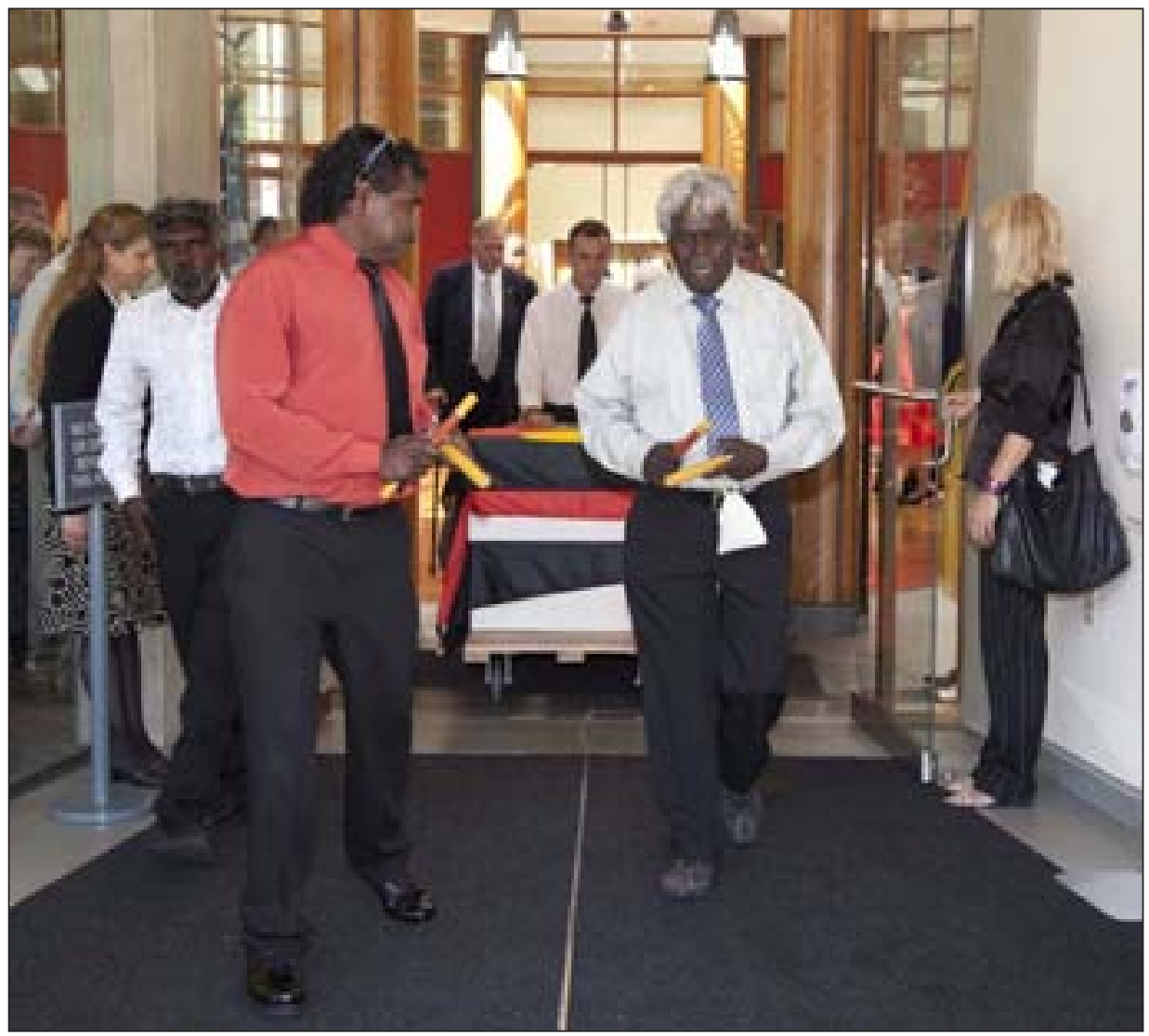

Figure 1.5 Victor Gumurdul of Gunbalanya (left), Thomas Amagula of Groote Eylandt and Joe Gumbula of Galiwinku (right) escorting the Arnhem Land human remains as they leave the Smithsonian Institution, 2009

Photograph by Adis Hondo

33 This account is based on personal discussions with officials involved in the case. A report by the $\mathrm{ABC}$ journalist Danielle Parry is likely to have caused particular embarrassment to the Smithsonian Institution. See $<$ http://www.youtube.com/watch?v=oB-Oqe9Fxes $>$ (viewed 20 December 2010). 
Just as the 1948 Expedition had many precedents, this study of it contributes to an enormous literature. Explorations and expeditions have long been fodder for historians. In national-history writing, the narratives concerning them were often conspicuous for their triumphalism. These days, we can expect a more critical and reflective analysis. Since the 1990s, scientific and anthropological fieldwork have been put under the microscope in a multitude of ways. Among the influential edited collections that appeared in that decade were Darwin's Laboratory (1994), a study focused on fieldwork in the Pacific and its impact on science, edited by Roy MacLeod and Philip F. Rehbock. ${ }^{34}$ In the United States, Edward C. Carter's Surveying the Record: North American Scientific Exploration to 1930 (1999), based on a conference at the American Philosophical Society, provided a comparative approach to science in the field. ${ }^{35}$ The centenary of the Cambridge Expedition to the Torres Strait inspired a 1998 volume edited by Anita Herle and Sandra Rouse, while the 1894 Horn Scientific Expedition to Central Australia was the subject of a substantial collection of essays coedited by D. J. Mulvaney, the most influential historian of early Australian anthropology. ${ }^{36}$ These accounts are relevant here because the multidisciplinary Cambridge and Horn expeditions were important precedents for Mountford's 1948 initiative. Studies of individual expeditions have provided one way of investigating scientific study and collecting in cross-cultural contexts. Major studies of this nature are occurring within the Smithsonian Institution, as is evident, for example, in Paul Michael Taylor's web-based publication By Aeroplane to Pygmyland on the 1926 Dutch and American Expedition to New Guinea. ${ }^{37}$

Other investigations have focused on individuals or particular partnerships. Mulvaney's work on Baldwin Spencer, including the major biography and, more recently, collections of Spencer's correspondence from Francis Gillen and other outback collaborators, is a foundational contribution to the history of anthropology. ${ }^{38}$ Queensland ethnographer Walter Edmund Roth and his

\footnotetext{
34 MacLeod, R. and Rehbock, P. F. (eds) 1994, Darwin's Laboratory: Evolutionary theory and natural history in the Pacific, University of Hawai'i Press, Honolulu.

35 Carter II, E. C., (ed.) 1999, Surveying the Record: North American scientific exploration to 1930, Memoirs of the American Philosophical Society, vol. 231, Philadelphia.

36 Herle, A. and Rouse, S. (eds) 1999, Cambridge and the Torres Strait: Centenary essays on the 1898 anthropological expedition, Cambridge University Press, UK; and Mulvaney, D. J. and Morton, S. R. (eds) 1996, Exploring Central Australia: Society, the environment and the 1894 Horn expedition, Surrey Beatty \& Sons, Chipping Norton, NSW.

37 Taylor, P. M. 2006, By Aeroplane to Pygmyland, viewed 10 November 2010, <http://www.sil.si.edu/ expeditions/1926/index.cfm>

38 Mulvaney, D. J. and Calaby, J. H. 1985, 'So Much That is New': Baldwin Spencer, 1860-1929. A biography, Melbourne University Press, Carlton, Vic.; Mulvaney, J., Morphy, H. and Petch, A. (eds) 2001, My Dear Spencer: The letters of F. J. Gillen to Baldwin Spencer, Hyland House, Melbourne; Mulvaney, J., Morphy, H. and Petch, A. (eds) 2000, From the Frontier: Outback letters to Baldwin Spencer, Allen \& Unwin, St Leonards, NSW.
} 
remarkable family were the subjects of a conference and book, while the ethnolinguist and material culture collector T. G. H. Strehlow is the subject of a major biography by Barry Hill. ${ }^{39}$ An important comparative study of individual collectors, developed from a conference at the Museum of Victoria, was published as The Makers and Making of Indigenous Australian Museum Collections (2008). ${ }^{40}$ My own work on early Australian anthropologist R. H. Mathews developed concurrently with these conferences and publications. ${ }^{41}$

Among the scholars of Arnhem Land, Ronald and Catherine Berndt, who were contemporaries - and rivals - of Mountford, and who likewise hailed from Adelaide, are historically the most influential. But it is the anthropologist Donald Thomson who has to date received the most sustained attention, most recently for the inspiration of his work upon the film Ten Canoes (2006). ${ }^{42}$ Thomson, who was in Arnhem Land before and after the 1948 Expedition, assembled outstanding material culture collections and was an exquisite photographer. The contemporary anthropologist Nicolas Peterson has played a particular role in investigating Thomson's legacy and encouraging debate about his work. ${ }^{43}$ Thomson-another individual whose career was sabotaged by Elkin-has come into his own in recent years because the visual ethnographic record he excelled in making has had particular impact on Arnhem Land cultures today. Since the 1990s, it has become increasingly standard in Aboriginal studies to take historical source material, including film and photographs, back to the places of origin for interpretation. In the 1990s, the visual anthropologist Roslyn Poignant repatriated to the Arnhem Land community of Maningrida photographs taken by her late husband, Axel Poignant, in the early 1950s. Her account of this process is a compelling study of how the medium of photography has been incorporated into Aboriginal knowledge systems, and it has provided inspiration to many subsequent researchers. ${ }^{44}$

39 Hill, B. 2002, Broken Song: T. G. H. Strehlow and Aboriginal possession, Knopf, Milsons Point, NSW; McDougall, R. and Davison, I. (eds) 2008, The Roth Family, Anthropology, and Colonial Administration, Left Coast Press, Walnut Creek, Calif.

40 Peterson, N., Allen, L. and Hamby, L. (eds) 2008, The Makers and Making of Indigenous Australian Museum Collections, Melbourne University Publishing, Carlton, Vic.

41 Thomas, M. (ed.) 2007, Culture in Translation: The anthropological legacy of R. H. Mathews, ANU E Press and Aboriginal History Incorporated, Canberra; Thomas, M. 2011, The Many Worlds of R. H. Mathews: In search of an Australian anthropologist, Allen \& Unwin, St Leonards, NSW.

42 See Davis, T. 2007, 'Remembering our ancestors: cross-cultural collaboration and the mediation of Aboriginal culture and history in Ten Canoes (Rolf de Heer, 2006)', Studies in Australasian Cinema, vol. 1, no. 1; Thomas, M. 2010, 'The crackle of the wire: media, digitization and the voicing of Aboriginal languages', in N. Neumark, R. Gibson and T. Van Leeuwen (eds), Voice: Vocal aesthetics in digital arts and media, MIT Press, Cambridge, Mass.

43 Thomson, D. F. 1983, Donald Thomson in Arnhem Land, (Compiled and introduced by N. Peterson), Currey O'Neil, South Yarra, Vic.; Rigsby, B. and Peterson, N. (eds) 2005, Donald Thomson: The man and scholar, The Academy of the Social Sciences in Australia, Canberra.

44 Poignant, R. with Poignant, A. 1996, Encounter at Nagalarramba, National Library of Australia, Canberra. 
The recognition that expeditions and other types of cross-cultural research can be of service to Indigenous communities is the most critical distinction between the approach taken in this book and much of the earlier literature on fieldwork and exploration (including great swathes of post-colonial critique, where the views of colonised people are considered only from a theoretical point of view). That distinction is fully evident in the chapter by ethnomusicologists Allan Marett and Linda Barwick, who, during long careers of recording and studying Aboriginal music in northern Australia, have helped get computers into communities and loaded them with archival song recordings and other historical material. They movingly describe how Colin Simpson's radio feature about a funeral rite at Delissaville (now Belyuen) was subtly alluded to in the choice of movements by dancer David Rankin during a recent funeral at which Barwick was present and in which Marett participated by singing. Significantly, this allusion did not involve a straightforward emulation of the historical material. Rather, the documentation provided 'a locus for the generation of new stories and narratives'. Marett and Barwick suggest that the internalisation of Simpson's recordings by Rankin and others in the community 'played a part in generating the shared understandings' that allowed them, as outsiders, to be drawn more deeply into the ceremony. This is part of a larger cultural shift within Arnhem Land today. Barwick has written elsewhere about the effect of digitisation on ethnographic archives, transforming them from institutions that serve researchers into ones that service the original knowledge holders or their descendants. ${ }^{45}$ This has resulted in significant initiatives within communities, aimed at the education of young people among other agendas. Yirrkala, for example, has the Mulka Centre, a community database for the storage and accessing of digitised photography, recorded sound and moving image. ${ }^{46}$ It is an outstanding example of how the ethnographic record can serve the interests of relevant knowledge holders. In this fast-moving environment, films and photographs - sometimes dismissed as the ephemera of the anthropological enterprise-acquire a wholly different value. It is in this context that the vast, if disputed, legacy of Charles Mountford-including the Arnhem Land Expedition-has come to attention.

Not only did the Expedition study what for its members were exotic cultures, it created a micro-culture of its own. Despite some notorious internal tensions, especially between Mountford and Frederick McCarthy, lifelong friendships developed. Membership was a badge of distinction for all involved. A commonality of experience bound the veterans of the Expedition. Many stayed in touch with one another and reunions were organised for the major anniversaries.

45 Barwick, L. 2004, 'Turning it all upside down...: imagining a distributed digital audiovisual archive', Literary and Linguistic Computing, vol. 19, no. 3. See also Thomas, M. 2007, 'Taking them back: archival media in Arnhem Land today', Cultural Studies Review, vol. 13, no. 2.

46 See <http://www.yirrkala.com/mulka/index.html > (viewed 1 December 2010). 
Both Setzler and ichthyologist Robert Miller made the long journey across the Pacific to attend such events in Australia. Their numbers inevitably diminished as the decades passed. The surviving members ate, drank, reminisced, and sang some of the comic songs that they had first performed around the campfire (for an example, see May, this volume). Most of the planning and preparation for the symposium that inspired this book occurred in 2008 - the sixtieth anniversary. The symposium itself was in late 2009. We were consciously building on the earlier tradition of anniversary celebrations, and the event was attended by Expedition botanist, Raymond Specht, and relatives of many other participants. Sadly, ill health prevented Peter Bassett-Smith, the other surviving Expedition member, from attending. Some observers from afar assumed that celebration was the sole motive in organising the event. That is simplistic - although all the organisers, of whom I was one, felt there were things to celebrate in the Expedition's legacy, particularly its contribution to greater cross-cultural understandings. Many Arnhem Land people of my acquaintance have similar views. The original appeal for scholarly papers noted that, with the passage of six decades, it would be timely 'for celebration, re-evaluation, and renewed collaboration between the individuals, institutions, and countries touched by this formative research venture'. As the contents of this book reveal, we received a multitude of responses from around the world - more than could possibly be included in the program. It is a casual reader indeed who would claim that this study of the Expedition is a panegyric. In working with the contributors, and seeing the spoken papers develop into the chapters of this book, I have come to think that the tripartite objectives of celebrating, evaluating and collaborating have been thoroughly pursued, and that they create an interesting internal tension within the volume.

That we achieved this is due to the truly seismic distinction between our public event that was Barks, Birds \& Billabongs in 2009 and the private anniversaries of previous years. Here I refer to the substantial representation from the main Aboriginal communities visited by the Expedition. Any thought that this would be a standard academic conference was utterly dispelled by this reality, and I hope that its effects are registered in the book. It should be noted that the contributions of Arnhem Land delegates did not include the giving of papers in English. In that respect, this book - a representation of the more academic component - is a partial record. The people from Arnhem Land, many of whom were visiting Canberra for the first time, have as their first language Bininj Kunwok, Iwaidja, Anindilyakwa or one of the clan-based languages known collectively as Yolngu Matha. Paper writing is not their cultural form. Their participation took the form of community panels, where issues such as the theft of human remains were movingly addressed. Film and photography were interpreted, and magnificent performances were given, including the epic Currents from a Distant Shore: Birrkili Yolngu songs of Makassan contact in 
Northeast Arnhem Land, led by Djangirrawuy Garawirrtja of Milingimbi and produced by musicologist Aaron Corn. Recordings and documentation of much of the event are permanently available on the National Museum of Australia's web site. ${ }^{47}$ Arnhem Landers made behind-the-scenes visits to the National Museum's off-site storage and other collections, while many pursued business among themselves. As those of us who work in Arnhem Land are aware, the symposium itself has left an enduring imprint on many who participated, as Margo Neale explains in her Epilogue.

When arranging the volume, and identifying common themes in the disparate chapters, it became apparent that they fall into three (admittedly overlapping) categories, each of which has become a section of the book. The first, 'Engagements with Aboriginal Cultures', positions the Expedition narrative in the context of Western structures, institutions and fields of knowledge. In this, it makes a compelling argument about the interest of Westerners in Australia's Aboriginal cultures, and how the engagements resulting from that interest affected modernity in the postwar era. There are eight chapters, bracketed between Philip Jones's account of Mountford and Sally May's description of the Expedition's origins, bases and activities. Jones provides a considered evaluation of the Expedition from Mountford's point of view. In sketching the background, he gives an illuminating account of Mountford's participation in the Board of Anthropological Research expeditions that went north from Adelaide in the 1930s. They were Mountford's introduction to the expedition experience and they opened a door to the living cultures of Aboriginal art that preoccupied him for the remainder of his life. Mark Collins Jenkins, formerly a historian for the NGS, gives a portrait of the Expedition's chief photographer, and in the process turns the lens upon a golden age at National Geographic. Kim Beazley also gives an inside perspective, opening up the political scene of Chifley, Calwell, Evatt and Menzies, and exploring the remarkable and highly confessional correspondence between Calwell and Setzler, which lasted long into the Cold War. Tony MacGregor's evaluation of Simpson as a broadcaster and writer is an important contribution to the study of radio and to the writing of Simpson, whose world view was significantly altered by his stay in Arnhem Land. The Expedition's effect on the disciplines of anthropology, archaeology and botany are considered in separate chapters. Jon Altman pursues the legacy of nutritionist Margaret McArthur, whose paper 'The Food Quest and the Time Factor', published in Volume 2 of the records, proved to be the Expedition's most enduring impact on anthropological theory when it was taken up by Marshall Sahlins to support his notion of the 'original affluent society'. Altman-like

47 <http://www.nma.gov.au/research/centre_for_historical_research/conferences_and_seminars/barks_ birds_billabongs/> (viewed 20 December 2010). 
Clarke and Frederick in their study of McCarthy as archaeologist-explains how the Expedition's legacy informed his own approach to fieldwork over a sustained period.

The second section - on collectors and collections - is integral to any study of the Expedition, for reasons already explained. The contributors offer a catholic range of responses to the subject. Archival collections are dealt with through the example of Walker's films and Mountford's papers. Louise Hamby, in her work on baskets and other fibre objects, and Robyn McKenzie, in her study of string figures, provide a significant corrective to the preoccupation with bark paintings that dominates popular perceptions of the Expedition. Both writers are informed by their own fieldwork experiences, where Expedition collections provide a stimulus for discussion at Milingimbi and Yirrkala respectively. Raymond Specht explains his approach to botanical collecting in an oral history, while the fish collections of Robert Rush Miller are considered in an elegant portrait by Gifford Hubbs Miller and Robert Charles Cashner (the son and sonin-law of the Expedition ichthyologist).

Five chapters make up 'Aboriginal Engagements with the Expedition' - the third and final section of the book. Here, the focus is on the Expedition's effect on the communities it visited. Some of these were rapid, as we see in Ian McIntosh's contribution, 'Missing the Revolution!', which addresses an astonishing event on Elcho Island, made famous to the world of anthropology through Ronald Berndt's classic monograph An Adjustment Movement in Arnhem Land (1951). For the secret-sacred culture of the Yolngu, the 'adjustment movement' signalled a revolutionary transformation by which formerly esoteric ceremonial objects, known exclusively to male initiates, were made public as an offering to nonAboriginal Australia in the expectation that the nation would reciprocate by sharing money, educational resources and material goods. Berndt claimed that it was a screening of an Arnhem Land Expedition film production showing secret ceremony - and thus indicating to Yolngu that their most cherished secrets had already been disclosed - that was the impetus for this development. McIntosh, who in the 1980s came under the mentorship of David Burrumarra - a protagonist in the adjustment movement - gives a rereading of the Expedition's ethnographic work in North-East Arnhem Land, based on what Burrumarra told him about the Bayini: an ancestral group of white people, said to predate the Macassans. Bayini narratives, according to McIntosh, provided a prism through which 'visitors to Arnhem Land since the beginning of time-including random and unplanned Indonesian visitors, explorers, trepanging Macassans, Japanese pearlers and Europeans (of all descriptions) - were explainable'. The interface between the esoteric world of Aboriginal religion and the putatively 'open' culture of scientific investigation is also at issue in Murray Garde's study of the Expedition's documentation of the Wubarr, a male initiation rite 
indigenous to Western Arnhem Land. Garde also writes of the offence caused by screenings of Expedition films, as happened at Gunbalanya before a mixed audience without prior consultation. But he also paints a more sanguine picture of the Expedition's documentation of culturally restricted material when it is repatriated in a consultative manner. He describes the joy with which the late Lofty Bardayal Nadjamerrek and other senior men received film and audio footage of this cherished ritual that has, since the 1970s, fallen into abeyance.

My own chapter on Gerald Blitner concerns his penetrating observations of the Expedition, recounted in the last year of his life during several days of oralhistory interview, and traces in his life story how encounters with Fred Gray, Mountford and other outsiders helped in the development of a political style that empowered him in his later negotiations with the Balanda world. The issue of how Aboriginal people engaged creatively with their new historical conditions is taken up in a very different way by Barwick and Marett in their fine-grained analysis of Simpson's song recordings from Oenpelli and Delissaville. From the mixture of genres and styles represented in these 'musical snapshots', they show how people were coping with the new social environments of missions and pastoral stations, where many were dislocated from ancestral country. The result was not cultural breakdown - as many outsiders have assumedbut innovation and collaboration between 'people from a number of different language groups, providing a rich multilingual social fabric in which marriage laws maintain diversity by demanding that people marry outside their own clan or language group'. Connections to traditional country were preserved in song, while 'ongoing attachments to their current residence' were also fostered.

A further and truly remarkable engagement with the Expedition is described in 'The American Clever Man' by Bruce Birch, a linguist who specialises in Iwaidja, traditionally spoken on the Cobourg Peninsula north of Gunbalanya, and now the dominant language on Minjilang (Croker Island). Birch recounts and analyses a story told to him by senior figures on Minjilang concerning an American scientist who visited the area, shot mammals and birds and then reanimated them, and who stole a deceased man by the name of Marrarna, whom he took home to America and brought back to life. The story was undoubtedly inspired by the Smithsonian's mammalogist David Johnson, who was a superb marksman and taxidermist, and whose epic solo walk through the Cobourg Peninsula was celebrated as one of the great feats of the Expedition. The scientist of this story is probably a fusion of various Expedition members. The documentary evidence indicates that it was Setzler, not Johnson, who robbed burial caves. Even so, the story is evidence of the concern raised by the theft of human remains and, as Birch writes, it gives compelling insight into how 'Indigenous people... tried to make sense of the activities of an alien culture in their midst', just as it 
emphasises how 'observation and analysis during the course of the Expedition were inevitably reciprocal in nature, the result of the interaction of two distinct culturally reinforced world views'.

The Arnhem Land Expedition's capacity to encourage thinking and empathy across cultures is the reason it retains relevance today. Peter Bassett-Smith recalled in an interview how Mountford often interrupted him when he was filming with the warning: 'Widen your scope!' It became a signature phrase within the Expedition party, and Peter wove it into at least one of his campfire songs. Comedy aside, engaging with the time capsule that is the 1948 Expedition is indeed a scope-widening experience. In illuminating a past event, it opens a conversation about the future. 